\title{
DESINFESTAÇÃO E ESTABELECIMENTO in vitro DE EXPLANTES DE BANANEIRA 'GRANDE NAINE' EM DIFERENTES CONCENTRAÇÕES DE HIPOCLORITO DE SÓDIO ${ }^{1}$
}

\author{
GUSTAVO ALVES PEREIRA ${ }^{2}$, LUIZ DE SOUZA CORREA ${ }^{3}$, APARECIDA CONCEIÇÃO BOLIANI ${ }^{3}$
}

RESUMO - A maioria dos plantios de bananeira ainda é realizada utilizando mudas tradicionais, mas outros métodos de propagação, como a micropropagação in vitro, vêm sendo desenvolvidos e aperfeiçoados, para elevar a taxa de multiplicação em curto espaço de tempo e melhorar a qualidade da produção de mudas. Contudo, a contaminação é um dos maiores problemas desta técnica. Este trabalho teve por objetivo avaliar a eficiência da descontaminação de explantes de bananeira com o uso de diferentes concentrações de cloro ativo durante a assepsia do explante. O delineamento experimental utilizado foi inteiramente casualizado e constituído de cinco tratamentos e cinco repetições, sendo cada repetição representada por 5 explantes em diferentes concentrações de cloro ativo, sendo: T1 (testemunha, sem cloro ativo); T2 (0,5\%); T3 (1,0\%); T4 (1,5\%), e T5 (2\%). Os dados obtidos foram submetidos à análise de variância, e as médias, comparadas pelo teste de Tukey, a 5\% de probabilidade. Os resultados permitiram concluir que a maior eficiência dentre os tratamentos testados foi a imersão dos explantes em hipoclorito de sódio com $2 \%$ de cloro ativo, sendo as doses testadas não tóxicas aos explantes, permitindo o desenvolvimento normal dos mesmos, concluindo assim que essa concentração possa ser utilizada para o controle de contaminações para micropropagação de bananeira cv. Grande Naine.

Termos para indexação: cultura de tecidos de plantas, cloro ativo, Musa sp.

\section{DISINFESTATION AND ESTABLISHMENT OF IN VITRO EXPLANTS OF BANANA 'GRANDE NAINE' IN DIFFERENT CONCENTRATIONS OF SODIUM HYPOCHLORITE}

\begin{abstract}
Brazil is one of the world largest producers of bananas, with a planted and harvested area of 504.586 ha in 2006 (IBGE, 2008). Most of the banana plantations are still cultivated using the traditional rooted young plants, but other methods of propagation such as in vitro micropropagation are constantly being developed and improved, to increase the multiplication rate in short time and to improve the quality of the seedlings production. However, contamination is a major problem of this technique. This study aimed to evaluate the efficiency of decontamination of banana explants, using different concentrations of active chlorine during the sterilization of the explants. The experimental design was randomized and consisted of five treatments and five repetitions, each one of 5 explants, at different concentrations of active chlorine, T1 (control) without active chlorine, T2 (0,5\%), T3 (1,0\%), T4 (1.5\%) and T5 (2\%). The contaminations were subjected to analysis of variance and means compared by Tukey test at $5 \%$ probability. The results showed that the highest efficiency among the treatments was the immersion of explants in sodium hypochlorite solution with $2 \%$ active chlorine, and the doses tested were not toxic to the explants, allowing normal development of them, thus concluding that concentration can be used to control contamination in banana micropropagation. Index terms: Plant Cell Culture, active chlorine, Musa sp.
\end{abstract}

\footnotetext{
${ }^{1}$ Trabalho Sinfruit 025 - Simpósio Internacional de Fruticultura - Avanços na Fruticultura (17 a 21 Outubro)

${ }^{2}$ Engenheiro Agrônomo, Doutorando em Agronomia pela UNESP - Campus Câmpus de Ilha Solteira, Departamento de Fitotecnia, Tecnologia de Alimentos e Sócio Economia, Av. Brasil 56, Ilha Solteira, -SP, CEP 15385-000. E-mail: gustavo_apereira@yahoo.com.br ${ }^{2}$ Docente do Departamento de Fitotecnia, Tecnologia de Alimentos e Sócio Economia/UNESP - Câmpus Câmpus de Ilha Solteira, Av. Brasil 56, Ilha Solteira, -SP, CEP 15385-000. E-mail: 1correa@agr.feis.unesp.br boliani@agr.feis.unesp.br
} 


\section{INTRODUÇ̃̃O}

O Brasil é um dos principais produtores mundiais de banana. Em 2006, o País apresentou área plantada de 511.151 hectares e área colhida de 504.586 hectares (IBGE, 2008).

A propagação da bananeira (Musa sp.) pode ser feita de várias formas: por sementes (oriundas da sua inflorescência), ou vegetativamente por meio de mudas ou in vitro (PEREIRA et al., 2009). Pelo método tradicional, mesmo o material sendo de ótima qualidade, o processo é lento e permite a disseminação de doenças e pragas (SILVA SOUZA et al., 2006).

A utilização de técnicas modernas de biotecnologia, como a cultura de tecidos, a manipulação genética e a biologia molecular, está sendo utilizada para o melhoramento genético de plantas, permitindo assim o desenvolvimento de novas variedades. Dentre as diversas práticas de cultura de tecidos, uma das mais utilizadas é a micropropagação, que atualmente é responsável pela produção de mudas de diversas espécies, com fins comerciais (PEREIRA, 2004).

A primeira aplicação comercial da micropropagação foi feita por Morel, no ano de 1960, ao multiplicar orquídeas, mediante cultura de ápices caulinares e regeneração de protocormos, diminutas estruturas que se diferenciavam e davam origem a embriões (CARVALHO et al., 2006).

Um dos princípios básicos para o sucesso da cultura de tecidos depende, em parte, de medidas de controle e prevenção da contaminação microbiana (LEIFERT et al., 1994; SILVA et al., 2003), devido a esta técnica proporcionar um ambiente favorável para o crescimento de microrganismos, como bactérias, leveduras e fungos filamentosos (DANTAS et al., 2002).

Os microrganismos contaminantes competem com os explantes pelos nutrientes do meio de cultura, eliminando no meio metabólitos tóxicos, podendo ocasionar a morte da plântula (PEREIRA et al., 2003).

O sucesso da micropropagação depende da sequência de fases ou etapas, em que o êxito de cada uma é necessário para o êxito da próxima etapa e a introdução do explante no meio de cultivo (estabelecimento), cujo sucesso depende de uma eficiente assepsia dos explantes a serem estabelecidos (GEORGE, 1993).

$\mathrm{Na}$ fase de estabelecimento do cultivo, a contaminação pode comprometer o trabalho de micropropagação. Quando é exógena, a possibilidade de controle dos principais agentes contaminantes (fungos e bactérias) é considerável; quando a contaminação é endógena, as consequências podem ser limitantes, podendo haver perda de tempo, de recur- sos financeiros e de material genético (SOUZA et al., 2006). Para minimizar a contaminação microbiana, inúmeros protocolos de esterilização são apresentados por diversos autores. Estes relatam o uso de substâncias, como hipoclorito de sódio (PEREIRA et al, 2009) e, em alguns casos, a adição de antibióticos ao meio de cultura (PEREIRA et al., 2009; ERIG; SCHUCH, 2003; TANPRASERT ; REED, 1998; REED et al., 1998). Assim sendo, a utilização de antibióticos é uma importante ferramenta para o controle de contaminações bacterianas endógenas, que frequentemente representam sérios problemas no estabelecimento das culturas (GRATTAPAGLIA; MACHADO, 1998).

O objetivo deste trabalho foi avaliar as diferentes concentrações de cloro ativo no controle de contaminações de explantes de bananeira cv. 'Grande Naine', durante a assepsia dos explantes, na propagação in vitro.

\section{MATERIAL E MÉTODOS}

O presente trabalho foi desenvolvido no Laboratório de Biotecnologia da UNESP, Câmpus de Ilha Solteira. Os explantes utilizados foram obtidos de plantas-matrizes originadas de clones de Musa sp cv. Grande Naine, cultivada na FEPE (Fazenda de Ensino Pesquisa e Extensão), UNESP, Câmpus de Ilha Solteira, localizada no município de Selviria (MS) distante a $13 \mathrm{~km}$ de Ilha Solteira (SP), no período de outubro-dezembro/2010. Após a obtenção dos rizomas, os mesmos foram lavados para retirar o excesso de solo e raízes. Em seguida, as bainhas foram seccionadas com uma faca estéril, permitindo assim a redução de seu tamanho.

Os tratamentos que constituíram o experimento foram: T1 (testemunha, sem cloro ativo); T2 $(0,5 \%$ de cloro ativo); T3 ( $1 \%$ de cloro Ativo); T4 (1,5\% de cloro ativo), e T5 (2\% de cloro ativo). A extração dos meristemas foi realizada em condições assépticas e incubados em meio de cultura MS (MURASHIGE; SKOOG, 1962), suplementado com sacarose a $30 \mathrm{~g}$ $\mathrm{L}^{-1}$ e mioinositol, e o solidificante Phytagel ${ }^{\circledR}$ a $2,5 \mathrm{~g}$ $\mathrm{L}^{-1}$, com $\mathrm{pH}$ ajustado para 5,8 antes da autoclavagem (esterilização) a $120^{\circ} \mathrm{C} \mathrm{com} 1 \mathrm{Kgf} \mathrm{cm}^{-2}$, durante vinte minutos. A fase de estabelecimento foi realizada em sala de crescimento, com temperatura $25 \pm 2{ }^{\circ} \mathrm{C}$ e fotoperíodo de 16 horas de luz, a uma intensidade luminosa de $30 \mu \mathrm{mol} \mathrm{m} \mathrm{m}^{-2} \mathrm{~s}^{-1}$.

Os explantes foram avaliados após trinta dias, contados da data de inoculação; posteriormente, foi realizada uma nova avaliação, durante a fase de multiplicação, que ocorreu trinta dias após a primeira avaliação. Desta forma, o experimento totalizou ses- 
senta dias, com duas avaliações durante este período.

O delineamento experimental foi inteiramente casualizado, com cinco tratamentos e cinco repetições, sendo cada repetição representada por cinco explantes, totalizando cento e vinte e cinco explantes. Os dados obtidos foram submetidos à análise de variância, e as médias, comparadas pelo teste de Tukey, a $5 \%$ de probabilidade. Os dados foram processados pelo programa estatístico SISVAR.

\section{RESULTADOS E DISCUSSÃO}

De acordo com as análises de variância (Tabela 1), os tratamentos utilizando cloro ativo em diferentes concentrações para assepsia dos explantes resultaram em diferença significativa para as avaliações realizadas trinta dias após o início do trabalho. Verificou-se que o tratamento com cloro ativo, com maior eficiência, foi T5 com 2,0\% de cloro ativo, verificando $0 \%$ de contaminação (Tabela 1);o T1 com $100 \%$ de contaminação indica que sem o uso de cloro ativo impossibilita a continuidade do processo de micropropagação. Já em T2, observou-se 70\% de contaminação e, em T3, houve contaminação com $50 \%$. No experimento T4, obtiveram-se $20 \%$ de contaminação da bactéria.

Para o controle de fungo, a redução siginificativa de contaminações pode ser observada no tratamento com $2 \%$ de cloro ativo, obtendo-se $0 \%$ de contaminação. No tratamento 3 , contaminaram-se $40 \%$, sendo que, para o tratamento 1 , houve $100 \%$ de contaminação, provando com este resultado que, se houver contaminação por fungos, é derivado de manuseio laboratorial mal realizado.

Com relação à oxidação, verificou-se que o tratamento com $2 \%$ de cloro ativo apresentou a maior frequência, com $90 \%$, verificando assim que esta concentração permitiu acelerar o processo de oxidação, porém sem provocar a perda dos explantes. Os dados obtidos evidenciam os resultados obtidos por Vianna et al. (2003) que utilizaram como descon- taminantes para os explantes de mamoeiro apenas hipoclorito de sódio com concentração de $1 \%$, sendo impossível conseguir explantes sem sinais visíveis de contaminação, principalmente por bactérias.

Este trabalho concorda com Pereira et al. (2009), que obtiveram maior eficiência na descontaminação de explantes de bananeira 'IAC 2001', quando se utilizou hipoclorito de sódio com a dosagem de $1 \%$ de cloro ativo.

Moraes et al. (2007) verificaram que as concentrações de 2; 3 e 4\% de hipoclorito de sódio reduziram a contaminação das gemas axilares em abacaxizeiro, e também verificaram que a concentração de $2 \%$ de hipoclorito de sódio, durante 10 minutos, proporcionou menor contaminação e sobrevivência de gemas axilares de abacaxizeiro.

Para o estabelecimento in vitro de cultivares de pereira (Pyrus spp.), obtiveram contaminação bacteriana em 45,7\% das gemas e 18,8\% dos meristemas, utilizando-se como rotina de assepsia somente álcool a 70\% e hipoclorito de sódio (ERIG; FORTES, 2002).

Este trabalho corroboram Chaves et al. (2004), em Prunus sp., que verificaram baixo índice de contaminação em explantes tratados com hipoclorito de sódio nas concentrações com $0,5 \%, 1 \% 1,5 \%$ e $2 \%$. Nietsche et al. (2006) afirmaram que o hipoclorito de sódio é mais tóxico do que o hipoclorito de cálcio, e dependendo do tempo de imersão, pode ocorrer desidratação do explantes, porém as concentrações utilizadas foram eficientes na assepsia e não tóxicas aos explantes.

22 Naue et al. (2007) verificaram que a utilização de álcool a 70\% e hipoclorito de sódio não foram eficientes para controlar microrganismos contaminantes em explantes de Nicotiana tabacum.

Carneiro et al. (2000) observaram níveis de contaminação bacteriana inferior a 30\% em explantes de banana imersos em hipoclorito de sódio, porém não foi eficiente no controle de fungos. 
TABELA 1 - Contaminação de explantes de bananeira cv 'Grande naine', submetidos a diferentes concentrações de hipoclorito de sódio.

\begin{tabular}{lccc}
\hline Tratamentos & $\begin{array}{c}\% \\
\text { contaminação com } \\
\text { bactéria }\end{array}$ & $\begin{array}{c}\% \\
\text { contaminação } \\
\text { com fungo }\end{array}$ & $\begin{array}{c}\% \\
\text { oxidação }\end{array}$ \\
\hline T1 (Testemunha) & $100 \mathrm{a}^{4}$ & $88 \mathrm{a}^{3}$ & $15 \mathrm{a}^{1}$ \\
T2 (0,5\% de cloro ativo) & $70 \mathrm{a}^{3} \mathrm{a}^{4}$ & $80 \mathrm{a}^{3}$ & $30 \mathrm{a}^{1} \mathrm{a}^{2}$ \\
T3 (1,0\% de cloro ativo) & $50 \mathrm{a}^{3}$ & $40 \mathrm{a}^{2}$ & $48 \mathrm{a}^{1} \mathrm{a}^{2}$ \\
T4 (1,5\% de cloro ativo) & $20 \mathrm{a}^{2}$ & $24 \mathrm{a}^{2}$ & $60 \mathrm{a}^{2}$ \\
T5 (2,0\% de cloro ativo) & $00 \mathrm{a}^{1}$ & $00 \mathrm{a}^{1}$ & $90 \mathrm{a}^{3}$ \\
\hline CV $(\%)$ & 26,65 & 24,95 & 29,83 \\
\hline
\end{tabular}

*Valores seguidos de letras e números iguais não diferem entre si, pelo teste de Tukey, a $5 \%$ de probabilidade.

\section{CONCLUSÕES}

1. Utilizando-se de $2 \%$ de cloro ativo por 20 minutos reduz-se a contaminação por bactérias e fungos em explantes de bananeira 'Grande Naine' para posterior micropropagação.

2. $2 \%$ de cloro ativo apresentou maior oxidação dos explantes, porém não ocasiou a perda dos mesmos.

\section{AGRADECIMENTOS}

Universidade Estadual Paulista 'Julio de Mesquita Filho' (UNESP/ Ilha Solteira).

\section{REFERÊNCIAS}

CARNEIRO, M. de F.; SILVA, G.D da; XIMENES, P.A.; CARNEIRO, I.F.; BORGES, J.D. Avaliação de produtos na descontaminação de explantes de banana (Musa AAB cv. Maçã). Pesquisa Agropecuária Tropical, Goiânia, v. 30, n.1, p.29-35, 2000.

CARVALHO, J. M. F. C.; SILVA, M. M. A.; MEDEIROS, M. J. L. Fatores inerentes à micropropagação. Campina Grande: Embrapa, 2006. p. 11-25. (Documentos, 148).

CHAVES, A.C; SCHUCH, M.; WALMOR, B. Desinfestação de explantes de Prunus cv. Mr. S. 2/5 com hipoclorito de sódio e cálcio. Revista Brasileira de Agrociência, Pelotas, v.10. n.2, p. 249-250, 2004.

DANTAS, S.; OLIVEIRA, S.; CÂMARA, T. Contaminação microbiana no cultivo in vitro de plantas. Revisão Anual de Patologia de Plantas, Passo Fundo, v.10, p. 391-407, 2002.
ERIG, A C.; FORTES, G. R. Estabelecimento de pereira (Pyrus spp.) in vitro a partir de meristemas e gemas. Revista Ciência Rural, Santa Maria, v. 32, p. 577-582, 2002.

ERIG, A. C.; SCHUCH, M. W. Tipo de explante e controle da contaminação e oxidação no estabelecimento in vitro de plantas de Macieira (Malus domestica Borkh.) CVS, Maxigala e Mastergala. Revista Brasileira de Agrociência, Pelotas, n. 3, v.9, p. 221-227, 2003.

GEORGE, E.F. Plant propagation by tissue culture: the Technology. $2^{\text {nd }}$ ed London: Hardcover, 1993. p.98-165.

GRATTAPAGLIA, D.; MACHADO, M. A. Micropropagação. In: TORRES, A. C.; CALDAS, L. S.; BUSO, J. A. (Ed.). Cultura de tecidos e transformação genética de plantas. Brasília: Embrapa/ SPI, 1998. v. 1, p. 183-260.

IBGE. Censo agropecuário e produção agrícola nacional. 2008. Disponível em: <www.ibge.gov.br>

LEIFERT, C.; MORRIS, C.E.; WAITES, W.M. Ecology of microbial saprophytes and pathogens in tissue culture and field grown plants: reason for contamination problems in vitro. Critical Reviews in Plant Sciences, Netherlands, v.13, p. 139-183, 1994.

MURASHIGE, T.; SKOOG, F.A. A revised medium for rapid growth and bioassays with tobacco tissue cultures. Physiologia Plantarum, Copenhagen, v.15, n.3 p.473-497, 1962. 
NAUE, C.R.; BENITIZ, L.B.; MEDEIROS, C. V. Eliminação de contaminantes microbianos da cultura de tecidos de Nicotiana tabacum L. In: CONGRESSO INICIAÇÃO CIENTÍFICA, 16., 2007, Pelotas. Resumos... Faculdade de Agronomia Eliseu Maciel, 2007. p. 1-5.

NIETSCHE, S. Estabelecimento in vitro de explantes de três cultivares de bananeira. Ciência Rural, Santa Maria, v.36, n.3, p.989-991, 2006.

MORAES, A.M.; ALMEIDA, F.A.C.; FILHO, J.C. Desinfestação e estabelecimento in vitro de gemas axilares de abacaxizeiro. Tecnologia \& Ciência Agropecuária, João Pessoa, v.1, n.2, p.39-44, 2007.

PEREIRA, J.; FORTES, G. Toxicidade de antibióticos no cultivo in vitro da batata em meios semissólido e líquido. Pesquisa Agropecuária Brasileira, Brasília, n.11, v.38, p. 1273- 1279, 2003.

PEREIRA, J. E. S.; MATTOS, M. L. T.; FORTES, G. R. L. Identificação e controle com antibióticos de bactérias endofíticas contaminantes em explantes de batata micropropagados. Pesquisa Agropecuária Brasileira, Brasília, v.38, n. 7, p. 827-834, 2003.

PEREIRA, G. A. Uso do gene $\boldsymbol{x y} \boldsymbol{l} \boldsymbol{A}$ - xilose isomerase como agente de seleção na transformação genética de citros. 2004. 38f. Dissertação (Mestrado em Fitotecnia) - Escola Superior de Agricultura "Luiz de Queiroz", Universidade de São Paulo, Piracicaba, 2004.

PEREIRA, G. A.; RIBEIRO, B. V.; MARCÍLIO, H. C.; SANTAELLA, M. B. Desinfestação e estabelecimento in vitro de explantes de bananeira 'IAC 2001' em diferentes concentrações de hipoclorito de sódio. Tecnologia \& Ciência Agropecuária, João Pessoa, v.3, n.2, p.43-46, 2009.
REED, B.M.; MENTZER, J.; TANPRASERT, P.; YU, X. Internal bacterial contamination of micropropagated hazelnut: Identification and antibiotic treatment. Plant Cell, Tissue and Organ Culture, Netherlands, v.52, p. 67-70, 1998.

SILVA, J.T. S.; NHUT, D.T.; TANAKA, M.; FUKAI, S. The effect of antibiotics on the in vitro growth pesponse of chrysanthemum and tabacco stem transverse thin cell layers (tTCLs). Scientia Horticulturae, Amsterdam, v. 97, p. 397-410, 2003.

SILVA SOUZA, A; LEDO, C.A.S; SILVEIRA, D.G; SOUZA, F.V.D; FARIA, G.A; NETO, H.P.S; SANTOS SEREJO, J.S; SILVA, K.M; COSTA, M.A.P.C; SOARES, T.L; JUNGHANS, T.G; ALMEIDA. W.B. Introdução à micropropagação de plantas. Cruz das Almas: Embrapa Mandioca e Fruticultura, 2006. p. 11-151.

TANPRASERT, P.; REED, B. Detection and identification of bacterial contaminants os strawberry runner explants. Plant Cell, Tissue and Organ Culture, Netherlands, v.52, p.53-55, 1998.

VIANNA, G.R.; COUTO, F. A. A.; OLIVEIRA, A. B.; ZAMBOLIM, L.; MARIA, J. A rifampicina na descontaminação bacteriana de explantes de mamoeiro provenientes do campo. Bragantina, Campinas, v.56, n.2, p.249-254, 2003. 